\title{
Problematic Terminology of the Manna Pericope (Exod 16:14-15) in the Light of Medieval Jewish Commentators and Biblical Hebrew Philology
}

\author{
HAim DiHi (BEN-GURION UNIVERSiTy OF THE NEGEV, ISRAEL)
}

\begin{abstract}
In this article, I shall discuss the adjective מחוספס and the word in the phrase מן-הוא, which both appear in the manna pericope in Exod 16:1415. I will present the different interpretations suggested by medieval Jewish commentators as well as modern scholars and dictionaries, and I shall attempt to show which one of the medieval interpretations is the most appropriate in the light of modern biblical philology. Medieval Jewish commentators suggested four different interpretations of the word מחוספס, two of which, "rounded" and "uncovered", have also been supported by the findings of modern biblical philology. Two medieval commentators rightly interpreted the word מן in the phrase מן-הוא an interrogative pronoun. This is also the commonly accepted interpretation in contemporary modern biblical philology.
\end{abstract}

KEYWORDS: Exod 16:14-15; Manna pericope; Jewish medieval commentators; Jewish medieval grammarians; modern biblical Hebrew philology; etymological equivalent; semantic equivalent; interrogative pronoun

\section{A INTRODUCTION}

When modern scholars of the Bible and biblical philology interpret unique or difficult words or phrases, they often rely exclusively on modern biblical exegesis and lexicology, and do not take into consideration the interpretations offered by medieval exegetes, grammarians and lexicographers. ${ }^{1}$ In not a few cases, the explanation commonly accepted in modern biblical philology has

* Submitted: 04/11/2019; peer-reviewed: 10/03/2020; accepted: 10/03/2020. Haim Deihi, "Problematic Terminology of the Manna Pericope (Exod 16:14-15) in the Light of Medieval Jewish Commentators and Biblical Hebrew Philology", Old Testament Essays 33 no. 2 (2020): 189 - 206. DOI: https://doi.org/10.17159/2312-3621/2020/ v33n2a3.

1 Chaim Cohen notes, in his article "Medieval Exegesis of Genesis and Modern Biblical Philology: Part I: Gen. 1-18," JQR 81 [1990]: 1, that only a minority of modern scholars take medieval exegetes and grammarians into consideration in their works, among them: H.M. Orlinsky in his commentary on the Pentateuch; Notes on the New (JPS) Translation of the Torah (Philadelphia, 1969); Weinfeld in his commentary on Genesis: M. Weinfeld, The Book of Genesis with a New Commentary [Hebrew], TelAviv, 1975. 
already been suggested hundreds of years ago by medieval exegetes and grammarians. True, these scholars did not have at their disposal modern philological tools, such as comparative Semitic linguistics and archaeological findings, often used by modern scholars. They also had no knowledge about the various Semitic and non-Semitic languages on which many modern scholars rely, such as Akkadian, Ugaritic, Canaanite, Aramaic, Arabic, and Egyptian. However, despite these "disadvantages", sometimes medieval scholars nevertheless arrived at the true or most probable explanation of a difficult word, by force of their developed linguistic sense and outstanding ability to understand the biblical text. ${ }^{2}$ For these reasons, it is befitting for any modern philological research, alongside the use of modern linguistic tools, to make systematic and critical use of medieval exegetical and grammatical works. In many cases, it will become apparent that the true explanation of those words or expressions is already found there. In the first part of the present study, I will examine how the medieval exegetes and grammarians explained the unique adjective מחוספס and the phrase מן-הוא, which also appears only in this biblical story. In the second part, I will present the modern exegesis of the word מחוספס and the phrase מן-הוא, and finally, I will show which of the medieval explanations is consistent with modern exegesis. As stated, the purpose of the study is two-fold: to provide the medieval exegetes and grammarians with a platform and to voice their opinions, and to demonstrate the great benefit modern philology may derive from the findings of medieval scholars.

\section{B THE ADJECTIVE}

The term מֶָ, the manna that the people of Israel ate in the desert, occurs fourteen times in the Bible: five times in Exodus 16, three times in Numbers 11, twice in Deuteronomy 8, twice in Joshua 5, once in Ps 78:24, and once in Neh 9:20.

In the book of Exodus 16:14, manna is described by two adjectives: דק "fine" (as frost) and מחוספס:

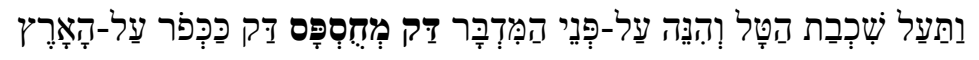

2 On the contribution of the medieval exegetes and grammarians to biblical philology and the need to consult their writings, see for example Cohen, "Medieval Exegesis," 1, 4-6, 8-11; idem, "Medieval Exegesis of Genesis and Modern Biblical Philology: Part Two," in Mas'at Aharon: Linguistic Studies Presented to Aaron Dotan (eds. Moshe Bar-Asher and Chaim E. Cohen; Jerusalem: The Bialik Institute, 2009), 25, 27, 29, 3131, 36; Sivan Daniel. "The Internal Passive of G-Stems in Northwest Semitic Languages," in Mas'at Aharon: Linguistic Studies Presented to Aaron Dotan (eds. Moshe Bar-Asher and Chaim E. Cohen; Jerusalem: The Bialik Institute, 2009), 51. Sivan notes that the internal passive of the qal conjugation was first identified by the medieval grammarians R. Yehuda Hayyuj, R. Yona ibn Janach, and Radaq. Chanoch Gamliel, "Rashi and the Hebrew Lexicon," Lěšonénu 73 (2011): 437, 440-446. 
"When the layer of dew had evaporated, behold, on the surface of the wilderness lay a fine and ground".

כזרע גד לבן "white like coriander seed" and its taste is said to resemble the taste of "בדבש appears only once in Biblical Hebrew, in this pericope. In Num 11:8, the manna is again לשד "rich cream". Relying on these attributes of the manna, we shall attempt, at the end of the discussion of this word, to point out the most reasonable interpretations of the word מחוספס.

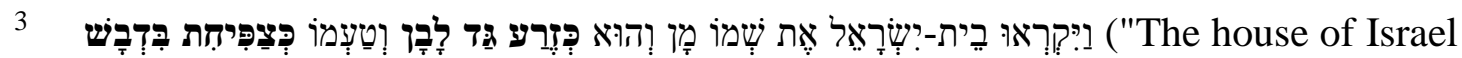
named it Manna, it was white like coriander seed, and it tasted like wafers in honey" [Exod 16:31]). גד is most likely the coriander plant. For this identification, see Francis Brown, Samuel R. Driver, and Charles A. Briggs, A Hebrew and English Lexicon of the Old Testament (Oxford: Clarendon Press, 1907), 151 (BDB); Ludwig Koehler, Walter Baumgartner, and Johann J. Stamm, The Hebrew and Aramaic Lexicon of the Old Testament (translated and edited by Mervyn E. J. Richardson; Leiden: Brill, 19942000), 1:176 (HALOT); Menahem T. Qaddari, A Dictionary of Biblical Hebrew (Ramat-Gan: Bar-Ilan University Press, 2006), 141.

4 Bdellium, a type of aromatic resin. In Akkadian: "budulhu" (Ignace J. Gelb, Benno Landsberger, A. Leo Oppenheim, and Erica Reiner, eds., The Assyrian Dictionary of the Oriental Institute of the University of Chicago, B [Illinois: Oriental Institute, 1965], 305-306 [CAD]). For which see Chaim Cohen, "'False Friend': Regular Meanings of Words in Modern Hebrew which Originated Erroneously," in Š ${ }^{e a}$ rê Lāšon: Studies in Hebrew, Aramaic, and Jewish Languages Presented to Moshe Bar-Asher (eds. Aharon Maman, Shmuel Fassberg, and Yohanan Breuer; Jerusalem: The Bialik Institute, 2007), 1:27-43: 36-39; idem, "New directions in modern biblical Hebrew lexicography," in Birkāt šâlôm: Studies in the Bible, Ancient Near Eastern Literature, and Postbiblical Judaism Presented to Shalom M. Paul on the occasion of his Seventieth Birthday (eds. Chaim Cohen, Victor A. Hurowitz, Avi M. Hurvitz, Yochanan Muffs, Baruch J. Schwartz, and Jeffrey H. Tigay; Winona Lake, Ind.: Eisenbrauns, 2008), 441-473: 465470.

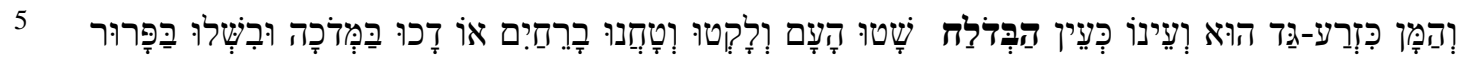
Now the manna was like coriander seed, and its appearance like that of bdellium. The people would go about and gather it and grind it between millstones, or pound it in a mortar, and boil it in a pot, and make cakes of it. It tasted like rich cream" [Num 11:7-8]). 
In Modern Hebrew, the adjective מחוספס is usually explained as meaning "not smooth, rough, bumpy" or "coarse, unrefined, unpolished". 6 The Talmud" interpreted the noun homiletically: "What is the meaning of the word מחספס? Resh Lakish said: It is something that melts on the wrist of the hand. ${ }^{8}$ Johanan said: [It means] something which is absorbed by the two hundred and forty-eight limbs". ${ }^{9}$ We shall now turn to the medieval Jewish commentators in order to observe how they interpreted this adjective. As we shall see below, many explanations have been offered for the adjective מחוספס, both in the middle ages and in modern times, which in fact shows that the exegetes found this word difficult to understand. In my opinion, the main reason for this difficulty lies in the fact that it appears only once in the entire Bible, as an adjective of the heavenly food called מן ("manna"), the nature, shape and appearance of which are entirely unknown. This claim is reinforced by the fact that the Septuagint does not translate the word. Instead of translating it, the Septuagint brings the word גד, which is used to describe the manna in Exod 16:31 and Num 11:7. ${ }^{10}$

\section{Medieval Exegesis}

Among medieval Jewish commentators we find four different interpretations:

\section{la First Interpretation: "Roundish"}

This is the interpretation suggested by Rav Sa'adya Gaon. He translates the word מחוספ into the Arabic word מحرج (mudahraj), which means "rounded

6 Thus, for example, the dictionaries of Even-Shoshan (Avraham Even-Shoshan, Hāmmilôn Hāhạad̄̄š (The New Dictionary) (Jerusalem: Kiryat Sefer, 1980) and RābMillîm (Yaakov Choueka, Rab-Millîm [Melingo Ltd, 2000-2010], https://www.ravm ilim.co.il/naerr.asp.), entry מחספס.

7 B. Yoma $75 b$.

8 In Hebrew: נימח על פיסת היד, Resh Lakish clearly interpreted מחוספס as an acronym (see Rashi ad loc.).

9 The numerical value of the word מחוספס is 248, which is the number of limbs in the human body.

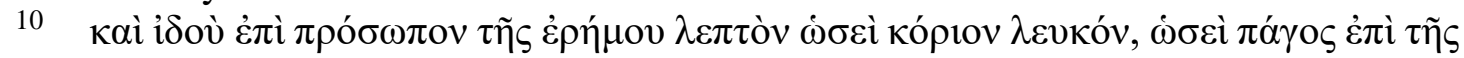
$\gamma \tilde{\eta}$ (="and behold, on the face of the wilderness [was] a thin thing like coriander, white as frost upon the earth"). https://biblehub.com/interlinear/apostolic/exodus/16.htm. It should be noted that some of the ancient translations, such as the Peshitta and Onkelos, did translate this word as they understood it on the basis of its context and etymology. In the Peshitta, the word מחוספס is translated into the word מקלף which means "peeled". Also, Onkelos uses this word (see below). The Peshitta adds another description to the is that does not appear in the Masoretic Text. Instead of the word ("thin") which according to the Masoretic text is repeated twice in the verse, the Peshitta translates the second appearance of the word מו מרים into the which means "covered". The two translations of the Peshitta - "peeled" (uncovered) and "covered" - seem to contradict each other. 
like a small ball"/"roundish". ${ }^{11}$ This is also the opinion of R. Abraham ibn Ezra, who rejects the interpretation "uncovered" (see below). He claims that there are no cases in which only the second root letter is doubled. R. Yonah ibn Janāh interprets the noun מחוספס in a similar manner, as meaning "rolled up", "round". ${ }^{12}$ In Sefoer Hahaśś $\bar{a} g \bar{a}$ he claims that there exist original quadrilateral roots, as for example the adjective מחוספס. ${ }^{13}$ Ibn Janāh also discusses the root of this word in three different places in Sefcer Hāriqmā. ${ }^{14}$ Radaq, in his dictionary, mentions the adjective מחוספס as a quadrilateral root (חספס), and explains it in the same manner: "rolled up", "round". ${ }^{15}$ Radaq also mentions the translation of Onqelos, who derives the adjective from the root חש" "to uncover". 16

\section{$1 b \quad$ Second Interpretation: "Uncovered"}

This is the first interpretation suggested by Rashi, ${ }^{17}$ which is also reflected in the Aramaic translation of Onqelos מקלף "peeled, uncovered". ${ }^{18}$ Nachmanides follows Onqelos. He derives the noun מחוספס from the root משוספ, ${ }^{19}$ through a doubling of the second root consonant $0 .{ }^{20}$ This opinion is also found in the

11 Yehuda Ratzaby, Rav Saadya's Commentary on Exodus (Jerusalem: Mossad HaRav Kook, 1998), 69.

12 Entry (Wilhelm Bacher, Sefer HaSchorashim: Wurzelwörterbuch der hebräischen Sprache von Abulwalîd Merwân Ibn Ganâh (R. Jona), aus dem Arabischen in's Hebräische übersesetzt von Jehuda Ibn Tibbon [Berlin: Itzkowski, 1896], 176).

13 David Téné, Sefoer Hahaśśāgā, which is Kitāb Al-Mastalhaq of Rabbi Jonah Ibn Janāh in the Hebrew Translation of Obadiah Ha-Sefaradi (Jerusalem: The Academy of the Hebrew Language and The Bialik Institute, 1996), 176.

14 Michael Wilensky, Sefar Hāriqmā, which is Kitāb Al-Luma of Rabbi Jonah Ibn Janāh (Jerusalem: The Academy of the Hebrew Language, 1964), 1:122; 1:183: 1:185. 15 Entry (Johann H. Biesenthal and Fürchtegoot Lebrecht, Rabbi Davidis Kimchi Radicum Liber [Berlin: Bethge, 1847], 124).

16 Thus, also Nachmanides and Menahem b. Saruq. On this suggestion, see below.

") מחספס - מגולה; ואין לו דמיון במקרא [...] ואונקלוס תרגם: "מקלף" - לשון "מחשוף הלבן" 17 - מחספס - uncovered; this is a hapax legomenon in Scripture. Onkelos rendered it as 'peeled away', like in מחשף הלבן ['a white surface, peeled away'; Gen 30:37]"); Rashi's commentary on Exod 16:14 (Mikraot Gedolot Ha-Keter, ed. Menahem Cohen, Exodus [Ramat Gan: Bar Ilan University Press: 2012], 1:136).

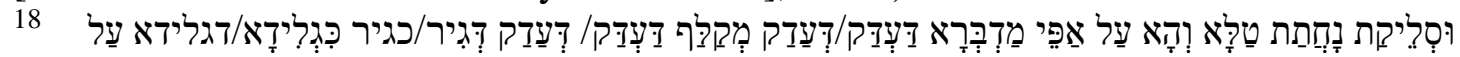
אַרְָָָא ("When the layer of dew lifted, there, over the surface of the wilderness, a thin and flaky substance, the thinness of chalkstone, like frost, lay on the ground". Targum Onkelos to Exod 16:14. (in Israel Drazin, Targum Onkelos to Exodus: An English Translation of the Text with Analysis and Commentary [New York: Ktav Publishing House, 1990], 2:168).

19 He notes that the letters $0 / ש$ ש often interchange.

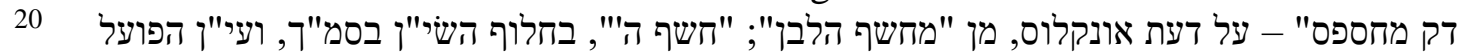

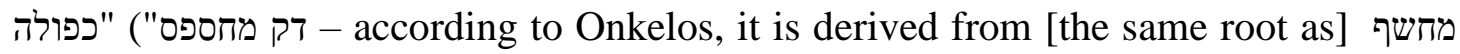
הלבן ['the white of the rods']; 'חשף ה' ['God has exposed'], the sin having interchanged with the [homophonous] sāmoek, and the second radical (the sāmoek of חסף) is doubled 
dictionary of Menahem b. Saruq. ${ }^{21}$ He derives the adjective from the root (=ף"ח $)^{22}$

\section{1c Third Interpretation: "Wrapped"}

This is the second interpretation suggested by Rashi. He derives the adjective חפ"ס from the root wrap). The manna was placed between the two layers of dew like in a wrapping or a package. ${ }^{23}$

\section{1d Fourth Interpretation: "Scattered"}

Rashbam suggests this interpretation on the basis of the context. The manna was scattered on the earth like frost. ${ }^{24}$

\section{Modern Scholarship}

We shall now turn to the findings of modern scholarship, in order to see which, if any, of the medieval interpretations is the most suitable or close to these findings.

Cassuto, in his commentary on Exodus, suggests explaining the adjective מחוספס as meaning "to be revealed" - this food was revealed/uncovered before the eyes of the people. ${ }^{25} \mathrm{He}$ adds that in Ugaritic the root

[and placed at the end of the word]"). Nachmanides' commentary on Exod 16:14 (Mikraot Gedolot Ha-Keter, Exodus, 1: 137).

21 Entry חספס (Angel Sáenz-Badillos, Mahberet Menahem Ben Saruq [Granada: Universidad de Granada, 1985], 183). As an additional example he brings מחשף הלבן.

22 This opinion is also found among modern translators. For example, the YLT (Young's Literal Translation) translates the words דק מחספס - "a thin, bare thing" (online: https://biblehub.com/exodus/16-14.htm).

23 In his commentary on Exod 16:14 (Mikraot Gedolot Ha-Keter, Exodus, 1:136)

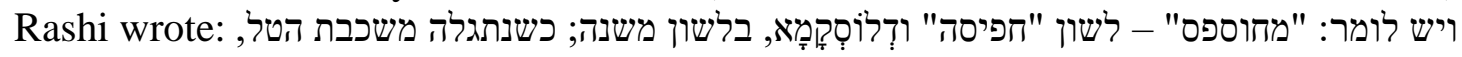
 that מהפיסה in the phrase 'a valise and a satchel', which is found in the language of the Mishna; when part of the layer of dew had been uncovered, they saw that there was something thin contained within it, between the two layers of dew"). This explanation is already found in the Babylonian Talmud (Yoma 75b). On the two explanations offered by Rashi and his preference towards the second one, see: Gamliel, "Rashi," 443.

24 - מחספס") מחספס - אין לו חבר, ופתרונו [לפי] עניינו - מפוזר " this word has no additional appearances in the Bible; its meaning according to its context is - scattered"; Rashbam's commentary on Exod 16:14 [in Martin I. Lockshin, Rashbam's Commentary on Exodus: An Annotated Translation (Atlanta: Scholars Press, 1997), 173]).

25 Umberto Cassuto, A Commentary on the Book of Exodus (Jerusalem: Magnes, 1952), 135. 
parallels the biblical root חש: means "to be revealed". ${ }^{26}$ The root sāmoek) does not exist in Biblical Hebrew. In Aramaic it means "clay, potsherd". In Biblical Hebrew the root חשש"ף (with sin) means "to uncover/expose". 27 However, it should be noted that the adjective מחוספס occurs in a book from First Temple times, while the interchanging of the letters $0 / w$ does not characterize Classical Biblical Hebrew of the First Temple times, only the Late Biblical Hebrew of the Second Temple times. ${ }^{28}$

BDB explains the adjective מחוספס as the result of the doubling of the root חס"ף. The adjective מחוספס is a shortened form of the noun מחספסף.29 The dictionary explains the adjective to mean "scale-like" or "scaled off". Etymologically, it compares the adjective to the Arabic verb خشف (chashafa), which means "to be scabby", "to scratch oneself". The dictionary notes that in general the Arabic consonant ش (sh) does not turn into O (s) in Hebrew. It also points out the Aramaic word חספינתא, which means "scale (of fish), scurf". 30

Ben-Yehuda ${ }^{31}$ finds the aforementioned suggestions unsound both etymologically ${ }^{32}$ and semantically. ${ }^{33} \mathrm{He}$ suggests explaining the adjective as meaning "formed like more or less round grains". He notes that the first one to

26 Ugaritic indeed contains the verb "tahspn" (tahsupuna), which mostly carries the meaning "to draw water, drain liquid", but not the general meaning "to be uncovered, revealed" (Daniel Sivan, A Grammar of the Ugaritic Language [Leiden: Brill, 2001], 119; Gregorio del Olmo Lete and Joaquin Sanmartín, A Dictionary of the Ugaritic Language in the Alphabetic Tradition [translated and edited by Wilfred G. H. Watson; Leiden: Brill, 2003], 1:373). However, as I demonstrate elsewhere ("The contribution of Mishnaic Hebrew to biblical Hebrew philology" [forthcoming]), there is a semantic connection between the roots חשש"ף/ער"ה - they can mean both "to uncover//expose" and "to pour from one vessel to another". In Ugaritic, there is an additional root [hsp], which means "to dry up" (it implies a sickly state in plants), a meaning which does not fit our context (Olmo Lete and Sanmartin, Dictionary, 1:410).

27 Also, Gesenius followed a similar path. He derived the adjective מחוספס from the root מש"ף/חס"ף, which means "uncovered" (alongside another suggestion: "like scales"). On the suggestion of Gesenius, see Arthur E. Cowley, Gesenius' Hebrew Grammar (28 ${ }^{\text {th }}$ ed.; Oxford: Clarendon Press, 1910), 153, §§55k.

28 Paul Joüon and Takamitsu Muraoka, A Grammar of Biblical Hebrew [Roma: Pontificio Instituto Biblico, 2006], 26-27, §5m.

29 BDB, 341.

30 According to Tal (Abraham Tal, A Dictionary of Samaritan Aramaic [Leiden: Brill, 2000], 1:325, n. 40), the Aramaic word is not חרספינא חספסינתא, as suggested by different scholars, but rather חרספיתא, חססט"פ which is derived from the root which later

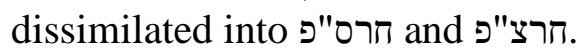

31 Eliezer Ben Yehuda, A Complete Dictionary of Ancient and Modern Hebrew (Berlin: Schöneberg, 1909-1959), 3:1676-1677 (in Hebrew).

32 For example, he rejects the claim that the word cannot possibly be derived from the quadrilateral root חספ, or from the root חס"ס.

33 For example, the suggestion "scale (of fish)". 
interpret in this manner was Rav Sa'adya Gaon (see above). Ben-Yehuda notes that an etymological parallel exists in Arabic haysafuj (حيسفوج). This word refers to a kind of seed that has the form of small balls. ${ }^{34}$

Qaddari, in his dictionary, explains the adjective as carrying the modern day meaning of "not smooth", "a thing with protrusions and cracks in it". $\mathrm{He}$ notes that the noun מחספסף מחוספס is a shortened form onso refers to the Jewish Aramaic parallel חספינתא, which means "scale".

The dictionary HALOT derives the adjective from the root 0 "ח..$^{36}$ It explains this adjective to mean "crackling", comparing it to the Arabic verb hasafa (خسف), which means "to crackle".

$\mathrm{Ta}^{37}$ suggests that מחוספס may mean "white" or "shining", on the basis of the Tosefta, which states that before the manna was cursed it would fall down on stubble and straw and turn white. ${ }^{38}$ According to Tal, a similar idea lies at the basis of the translation of Onqelos מקלף "peeled, uncovered". ${ }^{39}$ When the peel is removed, the matter that is exposed is shiny or white. In the margins of the Targum Neofiti, מחוספס is translated into the word "white". In the text itself we find the rendering: מפספס מפס "striped". "smashed", like the meaning of the root פספפ" in Talmudic literature, which resembles the meaning of פר"ך - "to squeeze", "to squash".

34 With regard to the interchanging of the Arabic letter 7 (jim) with the Hebrew o(sāmoek), Ben-Yehuda, relying on Brockelmann (Carl Brockelmann, Grundriss der vergleichenden Grammatik der semitischen Sprache, vol. 1 [Hildesheim: G. Olms, $1961] \S 45 \mathrm{~g}$ ), notes that this interchanging has certain precedents.

35 Qaddari, Dictionary, 329.

36 HALOT, 1:338.

37 Abraham Tal, "Lexicographic Studies", in Hebrew and Arabic Studies in Honour of Joshua Blau, (ed. Haggai Ben-Shammai; Tel Aviv/Jerusalem: Graphit, 1993), 325.

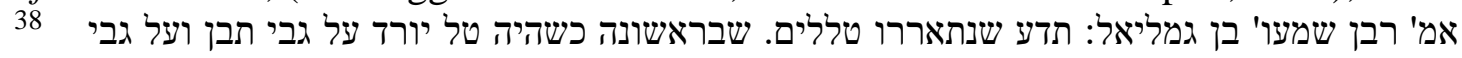
Rabban Simeon b. Gamliel Said: 'You should know that the dew has been cursed. In olden times, when the dew came down on straw and on stubble, it would turn white, as it is said: '... there was on the face of the wilderness a fine, flake-like thing ...', but now it turns black" [Tosefta Sotah 15:2, in Jacob Neusner, The Tosefta: Translated from the Hebrew with a New Introduction (Massachusetts: Hendrickson Publishers, 2002), 1:890]).

39 See above, n. 18.

40 Similarly, the translation attributed to Yonatan renders מסרגל "made up of lines".

41 On the roots פר"ך see for example Ben Yehuda, Dictionary, 10:50385039, 5181-5183; Marcus Jastrow, A Dictionary of the Targumim, the Talmud Babli and Jerushalmi and Midrashic Literature (New York: Pardes Publishing House, 1903), 2:1199, 1228; Menahem Moreshet, A Lexicon of the New Verbs in Tannaitic Hebrew (Ramat-Gan: Bar-Ilan University Press, 1980), 284, 291-292. 
A similar version is found in the Arabic translation of the Samarians, where the word ${ }^{42}$ מפרוך has the same meaning. In two other manuscripts of the Arabic translation ${ }^{43}$ we find the word מפרום in the same meaning. ${ }^{44}$

In the adaptation of the Arabic translation ${ }^{45}$ is found the Arabic word, mubaṣbaṣ, which means "to watch" and "to look out", although its root (bșș) means "glow" and "radiance". ${ }^{46}$ In the Samaritan Aramaic translation we find the verb מנצנץ, which may mean both "blossoming" and "shining". ${ }^{47}$

To sum up: it seems difficult to determine the exact meaning of the adjective מחוספס. However, what we can say is that some of the interpretations suggested by modern biblical philology had already been suggested by medieval Jewish commentators. For example, the explanation "rounded", suggested by Rav Sa'adya Gaon, Ibn Ezra, Ibn Janāḥ, and Radaq, was endorsed by BenYehuda. ${ }^{48}$ The interpretation suggested by Rashi (his first explanation), Menahem, and Nachmanides, which is based on Onqelos "peeled, uncovered" (מקלף), is supported by one of the interpretations suggested by Gesenius, and perhaps also by Cassuto.

One of the reasons for the difficulty in deciding between the different suggestions is that the identity of the manna remains unclear. ${ }^{49}$ Likewise,

\section{According to MS Barberini Or I.}

43 MSs Nablus 4 and 6. On the different versions of the Arabic translations of the Samarians, see Haseeb Shehadeh, The Arabic Translation of the Samaritan Pentateuch (Jerusalem: The Israel Academy of Sciences and Humanities, 1989-2002), 1:332.

44 Tal notes that in the Samaritan script the consonants $\triangleright$ and $\supset$ frequently interchange. 45 This adaptation was carried out by Abu-Said in the $13^{\text {th }}$ century. On the adaptation of the Arabic translation, see Shehadeh, Translation, 1:333; Tal, "Lexicographic Studies", 326.

46 On this root in Arabic, see Edward William Lane, Arabic-English Lexicon (New York: Frederick Ungar, 1955-1956), 1:209-210.

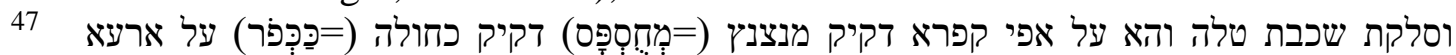
("When the fall of the dew lifted, there, over the wilderness, [lay] a fine and

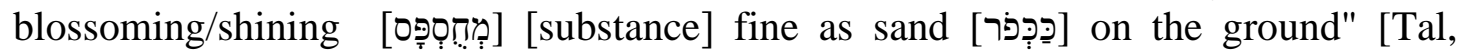
Dictionary, 2:544]). Tal notes that there exists a semantic connection between the

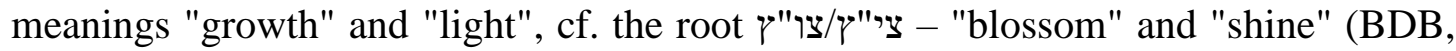
847; Qaddari, Dictionary, 909). The Samaritan translates ככפור with the word כחול (like sand"). Tal surmises that the translator might have understood this noun like Rav Sa'adya Gaon (it is well known that the Samarians made use of Sa'adya's translation) round like the sand of the seashore.

48 This is also the way taken by the following modern translations of the Bible: Nkjv; Kjb; Nheb; Akjv; Asv; Dbt; Erv; Wbt; Web. They translate the word מחוספס into the words "round" or "granular. For the modern translations of the Bible, see online: https://biblehub.com/exodus/16-14.htm.

49 Attempts have been made to identify it, but a convincing solution has yet to be found. One of the attempts was made by the scholars Bodenheimer, Kaiser, and Ubach. 
according to Held's method of Comparative Semitic Philology, etymological parallels do not in themselves constitute sufficient evidence. ${ }^{50}$ It is necessary to examine whether the Arabic and Aramaic parallels that have been suggested also serve in the context of food, and not only in the context of animals and skin afflictions (the word which means "scales").

Among the different solutions suggested, the one which equals the meaning of מחוספס in Modern Hebrew - "not smooth", "coarse" - as already suggested by some of the modern dictionaries (BDB, HALOT, Kaddari) seems to be the least suitable. ${ }^{51}$ This becomes clear in the light of the manna's remaining

They tried to identify the manna with a food found in the Sinai Peninsula created from the secretion of insects (=coccoidea) covering the trees, especially the tree named Tamarix Mannifera or Tamarix Gallica. The insects discharge small drops the size of a pinhead or pea, which look like water drops and glitter in the sun like dew (this secretion dripping from the tree is called "resin"). The drops dry and turn into whitish-orangebrown coloured sticky crystals. These drops serve as sustenance for various types of flying insects, particularly flies, which lay their eggs on them, which subsequently turn into maggots. The drops are also eaten by desert dwellers, who, due to their sweet, honey-like taste, consider them to be a delicacy. The Arabs call the food man or man min sama (man from Heaven; also in the Bible it is called "grain of Heaven" [Ps 78:24] and "bread of Heaven" [Ps 105:40]). This is the reason why the biblical story likens the appearance of the manna to crystal (see above n. 4), and notes that its taste resembles that of wafers made with honey. Others identify the manna with a certain desert bush. This bush breaks off and is carried away by the wind, and its branches have a sweet taste. On the attempts to identify the manna, see for example Cassuto, Commentary, 135; Martin Noth, Exodus: A Commentary (OTL) [London: SCM, 1962], 132; Samuel E. Loewenstamm, "Manna", in Encyclopaedia Biblica (eds. Benjamin Mazar, Jacob Liver, Samuel E. Loewenstamm, Naphtali H. Tur-Sinai, Chaim Rabin, and Samuel Yeivin; Jerusalem: The Bialik Institute, 1968), 7-10: 9 (in Hebrew); Aharon Shulov, "Manna", in Exodus (Olam Ha-Tanach Series; eds. Shemaryahu Talmon and Yitzhak Avishur; Tel-Aviv: Dodzon-iti, 1993), 5:104-105; The Editors of Encyclopaedia Britannica, "Manna," n.p. [cited 13 April 2020]. Online: https://www.britannica.com /topic/manna-plant-product\#ref275090.

50 Chaim Cohen, "The 'HELD method' for comparative Semitic philology," JANES 19 (1989): 14-15.

51 This is the direction taken by many of the English translations: Niv; Nlt; Esv; Bsb; Nasb; Ctb; Cev; Gnt; Hcsb; Isv; Nb; Gwj; Jps; Nas (online: https://biblehub .com/exodus/16-14.htm). They translated the word מחוספס into the word "flaky", which may be understood to mean thin and flat as a flake, or alternatively, rough as scales, which is the modern meaning of this adjective. If the modern translations intended to convey the first possibility, thin and flat, then they were probably relying on the additional descriptions of the מן; but if their intention was to convey the meaning scales/rough, like the modern meaning of the word - "scaly" - then they seem to have been influenced by the modern biblical dictionaries mentioned above. It is also possible that they deliberately chose to translate into "flaky" and not "scaly" in order to keep 


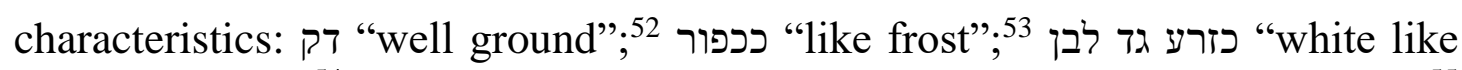
coriander seed"; עינו כעין הבדולח "its appearance was like that of bdellium".55 Loewenstamm notes that the resemblance to בדולח, when explained as aromatic resin, refers both to the sticky nature and to the light brown-yellow colour of the two materials, which do not possess characteristics such as "the opposite of smooth" or "coarse". 56

It may thus be inferred that the characteristics of מחוספס must resemble one of the latter descriptions.

\section{C מן THE WORD THE PHRASE מן-הוא IN THE}

The phrase מן-הוא occurs only in the manna pericope in Exod 16:15:

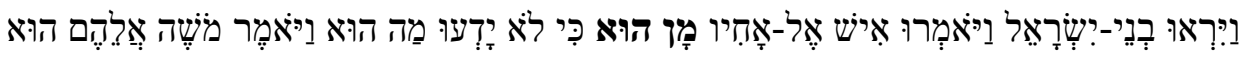

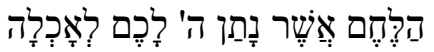

"When the Israelites saw it, they said to one another: ממוֹ הוּא - for they did not know what it was. And Moses said to them: 'This is the bread that God has given you to eat'".

Likewise, only in this verse does the word מן appear as an interrogative word with the meaning "what".

Among medieval Jewish commentators we find four different interpretations:

\section{$1 \quad$ Medieval Exegesis}

la First Interpretation: "Sustenance"

Rav Sa'adya Gaon explains מן as meaning "sustenance", paralleling the Arabic word مونة (mân) and مان (mî), which means "sustenance". 57

their translation open to both possibilities - the form of the was thin and flat, and its texture was the opposite of smooth

52 The opposite of thick (Qaddari, Dictionary, 193).

53 Water which has frozen into a thin layer of ice or snow (Qaddari, Dictionary, 527).

54 According to Qaddari, "the manna is likened to coriander seed due to the ball-like form of its fruits" (Qaddari, Dictionary, 141). ג is mentioned twice in Scripture, in both cases it describes the manna. See above, n.3.

55 בדולח is mentioned twice in Scripture: Gen 2:12; Num 11:7. See above, n.4.

56 Loewenstamm, "Manna", 9-10.

57 Ha'egron, Entry II מן (Něhemya Allony, Ha'egron, Kitāb 'ușūl Al-Shi'r Al'ibr' $\bar{a} n \bar{l}$ ) [Jerusalem: The Academy of the Hebrew Language, 1969], 300. About the Arabic words see Reinhart P.A. Dozy, Supplement aux Dictionnaires Arabes ( $3^{\text {rd }}$ ed.; Paris: G.P. Maisonneuve et Larose, 1967), 2:565-566. Like Rav Sa'adya Gaon, who understood the word sis a noun, so do two translations into foreign languages - the 


\section{$1 b \quad$ Second Interpretation: Preparation or Provision of Food}

Rashi connects the word מימן להם המלך : to Dan 1:5ich he apparently understands to mean "and the king prepared for them", since he explains מן לכל מכון to mean עכנת מזון - "preparation of food". explained the word in a similar way, explaining it to mean ערך - "arrangement" or "preparation". ${ }^{59}$ According to this explanation, the manna fell down from the sky already fit to be eaten.

Ibn Ezra rejects the possibility of explaining מן as the Hebrew parallel of the Arabic word meaning "what". He claims that the Arabic word means "who" and is used only in connection with human beings. Like Rashi, he derives the word from the root מנ"י but explains it to mean מימון - "summoning" or "providing". ${ }^{60}$ According to this understanding, the word מן does not come to emphasize that the manna fell down fit to be eaten (although Ibn Ezra most probably agreed to this), but the sheer fact that it was provided by Heaven.

\section{1c Third Interpretation: "what"}

Rashbam explains מן as meaning "what". He claims that this is an Egyptian word, a language which the people of Israel knew. ${ }^{61}$ Rashbam refers to additional

Kjv (English) and the Dutch State Translation - understand spas a noun functioning as predicate, and the pronoun הוא as the syntactic subject of the sentence. From the point of view of content and syntax, this possibility is less probable. In a nominal clause, the subject (here, the pronoun הוא) usually precedes the predicate, while in the verse under discussion an exceptional word order seems to have been employed, the predicate

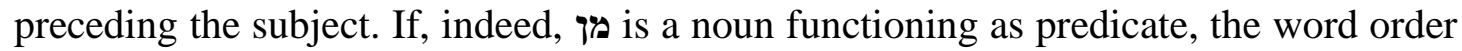
should have been: הוא הוא מצן (on the nominal clause and its characteristic word order, see for example: Joüon and Muraoka, A Grammar of Biblical Hebrew, 531$538, \S 154$ ea-h).

"מן הוא" - הכנת מזון הוא, כמו "וימן להם : "מthis phrase means:] it is preparation of nourishment, like in the phrase 'and the king prepared portions for them' (Dan 1:5). 'For they did know what it was' - so that they could call it by its proper name"). It should be noted that the use of the root מני in the pi'el conjugation with the meaning of "to allot, prepare food", "to appoint, assign, designate" is found mainly in books from the Second Temple period (Daniel, Chronicles. It occurs also in the book of Jonah and in late poetic texts). On this root, see for example Atalya Brenner, "The language of the book of Jonah as a measure for determining the time of its composition", Beit Mikra 24 (1979): 399-400.

59 Maḥberet Menaḥem, Entry מן (Sáenz-Badillos, Maḥberet, 242). As additional examples he brings in the verbs מימן (Jon 4:7) מנה (Dan 1:10).

60 Ibn Ezra's short commentary on Exod 16:15 (Mikraot Gedolot, Exodus, 1:136).

61 In his commentary on Exod 16:15 (Mikraot Gedolot Ha-Keter, Exodus, 1:136) "ויאמרו איש אל אחיו מן הוא" - לפי שלא ידעו מה הוא; וגם דונש פתר כן, כי סוף : Rashbam wrote המקרא מוכיח: "כי לא ידעו מה הוא". ואני אומר "מן הוא" - תרגומו של 'מי', ולפי שהוא לשון ישון מצרי 
examples of the Bible's use of words from foreign languages, such as which appears alongside גורל (Esth 3:7), and the phrase יגר שהדותא, appearing alongside the phrase גל-עד (Gen 31:46). Rashbam notes that also Dunash ${ }^{62}$ explained the word to mean "what", but in his opinion it is the Aramaic interrogative word מן גל, which usually means "who" but in this particular case it means "what". ${ }^{6}$

\section{1d Fourth Interpretation: "Kind"}

Ibn Janāh, in his dictionary, suggests three different interpretations of the word מין . מין 1 "species", "kind". He adds that although מין contains the letter', which is not found in מן, there exist additional examples of this kind of change. ${ }^{65} 2$. "To count", "to allot". 3. The Aramaic interrogative word מן, usually means "who", but in this case it carries the meaning "what". Ibn Janāh notes that all the interpretations are valid, but he personally prefers the first one: "kind". The people of Israel said about the manna, the unknown food, that it was a kind of food which they did not know. By preferring the first interpretation, Ibn Janāh ignores the immediate context.

\section{Modern Scholarship}

Ben-Yehuda explains the word ממן to mean "what", noting that this use is unique to the verse in Exodus. ${ }^{66}$

According to the currently accepted opinion, מן is an interrogative particle meaning "what". This interrogative particle, which is a regular Akk term mannu

\footnotetext{
ובאותו לשון היו רגילין שהוא כמו 'מה', כתבו משה באותו לשון שאמרו, להודיענו שלפיכך "ויקראו ...

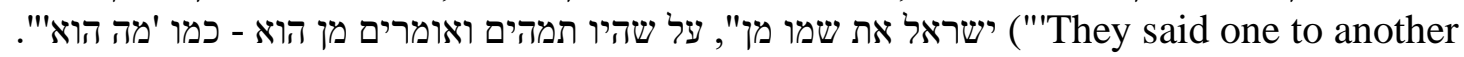
man $h u$ ' [which means 'what is it?] - because they did not know what it was; also Dunash explained [the phrase] in this way, relying on the continuation of the verse: 'for they did not know what it was'. In my opinion, however, man $h u$ is the [Aramaic] translation of 'who'; but since this phrase is written in the Egyptian language, and in that language the common meaning of man is 'what', Moses wrote the phrase in the precise language that people said it, in order to inform us that they were wondering [what is was], and they said man $h u$ - what is it?..." [the translation relies partly on Lockshin, Rashbam, 173-174]). Scholars have noted that Rashbam, obviously, did not know ancient Egyptian, and that his interpretation is based purely on conjecture (Lockshin, Rashbam, 174).

62 See Tzvi Filipowski, ed., Teshuvot Dunash ben Labrat (London, Edinburgh: Hevrat Me'orerei Yeshenim, 1855), 20.

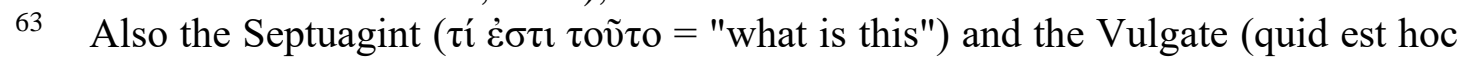
= "what is this") rightly understood the word מן as an interrogative meaning "what".

64 Entry מין (Bacher, HaSchorashim, 259).

65 Such as the word מיץ in Isa 16:4, which is the equivalent of the word מיץ in Prov 30:33.

66 Ben Yehuda, Dictionary, 6:3076.
} 
meaning "who" (as in Aramaic), ${ }^{67}$ occurs also in the Canaanite dialect of ElAmarna (manni, manna, mannu) meaning "what". ${ }^{68}$ It also occurs in Ugaritic mannu mn meaning "who, the one who", 69 in Jewish Palestinian Aramaic

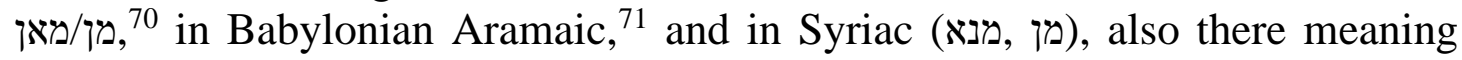
both "who" and "what". ${ }^{72}$ This is the interpretation accepted by Gesenius, ${ }^{73}$ Cassuto, ${ }^{74}$ Qaddari, ${ }^{75}$, Sarna, ${ }^{76}$ Loewenstamm, ${ }^{77}$ BDB,${ }^{78}$ and HALOT. ${ }^{79}$

To sum up: In this case, unlike the previous one, the meaning is unequivocal. מן is an interrogative word meaning "what". As shown, among medieval Jewish commentators, only Rashbam arrived at the right solution when explaining מן as an interrogative word meaning "what", in agreement with the findings of modern biblical philology. ${ }^{80}$ Although medieval Jewish commentators had no knowledge of those ancient Semitic languages on which modern scholars based this interpretation (Akkadian, Amarna Canaanite, Ugaritic), they nevertheless succeeded in arriving at the true solution, relying on

67 CAD M1, 213-218; Jastrow, Dictionary, 2:796.

68 CAD M1, 214-215; Anson F. Rainey, Canaanite in the Amarna Tablets: A Linguistics Analysis of the Mixed Dialect Used by Scribes from Canaan (Leiden: Brill, 1966), 1:103-108. According to Cassuto (Commentary, 135), the early Israelites probably spoke this language

69 Sivan, Grammar, 59. Olmo Lete and Sanmartin, Dictionary, 2:560.

70 Sokoloff, Palestinian Aramaic, 316-317. According to Sokoloff, the interrogative particle is which means both "what" and "who".

71 Michael Sokoloff, A Dictionary of Jewish Babylonian Aramaic of the Talmudic and Geonic Periods (Ramat-Gan: Bar-Ilan University Press, 2002), 636-637. According to Sokoloff, the interrogative particle is מן, which means both "what" and "who". In Babylonian Aramaic מנו means "what is it".

72 Robert P. Smith, Thesaurus Syriacus (Oxford: Clarendon Press, 1879-1901), 280; Michael Sokoloff, Syriac Lexicon: A Translation from Latin, Correction, Expansion, and Update of C. Brockelmann's Lexicon Syriacum (Indiana: Eisenbrauns 2009), 778.

73 Wilhelm Gesenius, Hebräisches und Aramäisches Handwörterbuch über das Alte Testament (18 ${ }^{\text {th }}$ ed.; Berlin: Springer-Verlag), 3:692.

74 Cassuto, Commentary, 135.

75 Qaddari, Dictionary, 625.

76 Nahum M. Sarna, Exodus: The Traditional Hebrew Text with the New JPS Translation (Philadelphia: Jewish Publication Society of America, 1989), 89, 249.

77 Loewenstamm, "Manna", 10.

78 BDB, 577.

79 HALOT, 2:596-597.

80 While Dunash and Ibn Janāh (in one of the three suggested interpretations) explained מן as an interrogative word, they relied on Aramaic, in which the regular meaning of מן is "who", claiming that only in this verse does it mean "what" (also in Biblical Aramaic we find the word מן מן מן אנון "..." שמהת גבריא..." ("what are the names of the men"; Ezr. 5:4. BDB, 1100). 
the context and additional languages (Aramaic and hypothetical ancient Egyptian).

\section{CONCLUSION}

The present study has presented the interpretations of the adjective מחוספס and the interrogative מן מן הוא in the phrase both medieval exegetes and grammarians as well as of modern Bible scholars. The purpose of the study was to demonstrate that some of the interpretations of modern scholars, which are based on the novel tools of research of biblical philology (Semitic languages, archaeological findings, etc.), had already been put forth hundreds of years before by medieval exegetes and grammarians. With regard to the adjective מחוספס, occurring only once in the Bible, medieval exegetes and grammarians have offered four different explanations: roundish (Rav Sa'adya Gaon, Ibn Janach, Ibn Ezra, Radaq); uncovered (Menachem, Rashi [first explanation, relying on Onkelos] Nachmanides); wrapped (Rashi, second explanation, which he himself prefers); scattered (Rashbam). Two of the explanations suggested by medieval exegetes have found support in modern biblical philology. The explanation "roundish", suggested by Rav Sa'adya Gaon, Ibn Janach, Ibn Ezra, Radaq, is supported also by Ben-Yehuda (as noted above, this is also the way taken by some of the modern translations into English); and the explanation "uncovered", suggested by Rashi (first explanation), Menahem, and Nachmanides, relying on Onkelos (מקלף), is supported by Gesenius and Cassuto. Also with regard to the interrogative מקן, which forms part of the phrase מן-הוא, also occurring once in the Bible, four explanations have been suggested: food (Rav Sa'adya Gaon); to prepare and arrange food (Menahem, Rashi, Ibn Janach, Ibn Ezra); interrogative "what" (Rashbam, Ibn Janach); kind and type (Ibn Janach). Also in this case, the explanation suggested by Rashbam and Ibn Janach, an interrogative meaning "what", constitutes the commonly accepted explanation in modern biblical philology. Although the medieval scholars had no access to those Semitic languages to which modern scholars have access (Akkadian, Canaanite, Ugaritic), and on which they base and enforce their analysis, the medieval scholars nevertheless arrived at the true explanation. These two examples, as well as numerous others suggested in various studies presented in this study, illustrate how the medieval exegetes, through their linguistic knowledge and the exegetical tools at their disposal, arrived at the true explanations of difficult biblical words and phrases, explanations that in many instances match the findings of modern biblical philology. The conclusion of this is that it is indeed appropriate for any modern research on biblical philology to take medieval exegesis into consideration, and often it will become clear that the modern explanations may be enforced by the findings of medieval exegetes and grammarians. 
204 Dihi, "Problematic Terminology," OTE 33/2 (2020): 189-206

\section{BIBLIOGRAPHY}

Allony, Něḥemya. Ha 'egron, Kitāo 'ușūl Al-Shi 'r Al- 'ibr'ānī. Jerusalem: The Academy of the Hebrew Language, 1969 (in Hebrew).

Bacher, Wilhelm. Sefer HaSchorashim, Wurzelwörterbuch der hebräischen Sparche von Abulwalîd Merwân Ibn Ganâh (r. Jona), Aus dem Arabischen ins Hebräische übersezt von Jehuda Ibn Tibbon. Berlin: Itzkowski, 1896.

Ben Yehuda, Eliezer. A Complete Dictionary of Ancient and Modern Hebrew. 17 vols. Berlin: Schöneberg, 1909-1959 (in Hebrew).

Blinder, Yaakov et al., Ramban, The Torah: with Ramban's Commentary, Translated, Annotated and Elucidated, 2 vols. New York: Masorah Publications, 2006.

Brenner, Atalya. "The language of the book of Jonah as a measure for determining the time of its composition". Beit Mikra 24 (1979): 396-405 (in Hebrew).

Brockelmann, Carl. Grundriss der vergleichenden Grammatik der semitischen Sprache, 2 vols. Hildesheim: G. Olms, 1961.

Brown, Francis, Samuel, R. Driver and Charles A. Briggs. Hebrew and English Lexicon of the Old Testament. Oxford: Clarendon Press, 1907 (BDB).

Buhl, Frants. Wilhelm, Gesenius' Hebräisches und Aramäisches Handwörterbuch über das Alte Testament. 18 ${ }^{\text {th }}$. 4.vols. Berlin: Springer-Verlag, 2005. https://doi.org/10.1007/978-3-642-62044-7.

Cassuto, Umberto. A Commentary on The Book of Exodus. Jerusalem: The Magnes Press, 1952.

Choueka, Yaakov. Rav-Milim. Melingo Ltd, 2000-2010. Online: https://www.ravmilim.co.il/naerr.asp.

Cohen, Chaim. "The 'HELD Method' for Comparative Semitic Philology". Journal of the Ancient Near Eastern Society 19 (1989): 9-23.

. "Medieval Exegesis of Genesis and Modern Biblical Philology: Part I: Gen. 118." Jewish Quarterly Review 81 (1990): 1-11.

"'False Friends': Regular Meanings of Words in Modern Hebrew which Originated Erroneously." Pages 27-43 in Sha'rei Lason, Studies in Hebrew, Aramaic and Jewish Languages presented to Moshe Bar-Asher. Edited by Ahron Maman, Steven E. Fassberg, Yochanan Breuer. 3 vols. Jerusalem: The Bialik Institute, 2007 (in Hebrew).

. "New Direction in Modern Biblical Hebrew Lexicography." Pages 441-473 in Birkat Shalom: Studies in the Bible, Ancient Near Eastern Literature, and Postbiblical Judaism Presented to Shalom M. Paul on the occasion of his Seventieth Birthday. Edited by Chaim Cohen, Victor A. Hurowitz, Avi Hurvitz, Yochanan Muffs, Baruch J. Schwartz, Jeffrey H. Tigay. Winona Lake, Ind: Eisenbrauns, 2008.

. "Medieval Exegesis of Genesis and Modern Biblical Philology: Part Two." Pages 25-46 in Mas'at Aharon: Linguistic Studies Presented to Aaron Dotan. Edited by Moshe Bar-Asher and Chaim E. Cohen. Jerusalem: The Bialik Institute, 2009 (in Hebrew).

Cowley, Arthur E. Gesenius' Hebrew Grammar. 28th ed. Oxford: Clarendon Press, 1910.

del Olmo Lete Gregorio and Joaquín Sanmartín. A Dictionary of the Ugaritic Language in the Alphabetic Tradition. Translated by Wilfred G. H. Watson. 2 vols., Leiden: Brill, 2003. 
Drazin, Israel. Targum Onkelos to Exodus: an English translation of the text with analysis and commentary. New York: Ktav Pub. House, 1990.

Even-Shoshan, Avraham. Ha-Milon Ha-Chadash (The New Dictionary) 7 vols. Jerusalem: Kiryat Sefer, 1980.

Filipowski, Zevi, ed., Teshuvot Dunash ben Labraț. London, Edinburgh: Hevrat Me'orerei Yeshenim, 1855.

Gmliel, Chanoch. "Rashi and the Hebrew Lexicon." Lěšonénu 73 (2011): 437-447. (in Hebrew)

Heinnrich, Johann, Raphael Biesenthal and Lebrecht, Fürchtegoot. Rabbi Davidis Kimchi Radicum Liber, Berlin: Bethge, 1847.

Herczeg Yisrael I. Z. et al. Rashi: The Torah: with Rashi's Commentary Translated, Annotated and Elucidated. N.Y: Mesorah Publications, 1999.

Jasrtow Marcus. A Dictionary of the Targumim, the Talmud Babli and Jerushalmi and Midrashic Literature. 2 vols. New York: Pardes Publishing House, 1903.

Joüon Paul and Takamitsu Muraoka. A Grammar of Biblical Hebrew. Roma: Pontificio Instituto Biblico, 2006.

Kaddari Menahem Z. A Dictionary of Biblical Hebrew. Ramat-Gan: Bar-Ilan University Press, 2006 (in Hebrew).

Koehler Ludwig and Walter Baumgartner, et al. The Hebrew and Aramaic Lexicon of the Old Testament. translated and edited by Mervyn E. J. Richardson. 5 vols. Leiden: Brill, 1994-2000 (HALOT).

Lane Edward W. Arabic-English Lexicon. 8 vols. New York: Frederick Ungar, 19551956.

Lockshin Martin I. Rashbam's commentary on Exodus: an annotated translation. Atlanta: Scholars Press, 1997.

Loewenstamm Samuel E. and Benjamin Mazar, et al. eds., "Manna", Encyclopaedia Biblica 5 (1968): 7-10 (in Hebrew).

Moreshet Menahem. A Lexicon of the New Verbs in Tannaitic Hebrew. Ramat-Gan: Bar-Ilan University Press, 1980 (in Hebrew).

Margoliouth, J Payne Smith . Thesaurus Syriacus. Oxford: Clarendon Press, 18791901.

Neusner Jacob. The Tosefta, Translated from the Hebrew with a New Introduction, III. Massachusetts: Hendrickson Publishers, 2002.

Noth Martin. Exodus, A Commentary (OTL). London: SCM, 1962.

Ratzaby, Yhuda. Rav Saadya's Commentary on Exodus. Jerusalem: Mossad Ha-rav Kook, 1998 (in Hebrew).

Rainey, Anson F. Canaanite in the Amarna Tablets, A Linguistic Analysis of the Mixed Dialect Used by Scribes from Canaan, 2 vols. Leiden: Brill, 1966.

Sáenz-Badilloos, Angel. Maḥberet, Menahem Ben Saruq. Granada: Universidad de Granada, 1985.

Sarna, Nahum M. Exodus, The Traditional Hebrew Text with the New JPS Translation. Philadelphia: Jewish Publication Society of America, 1989.

Shehadeh, Haseeb. The Arabic Translation of the Samaritan Pentateuch. 2 vols. Jerusalem: The Israeli Academy of Sciences and Humanities, 1989-2002.

Shulov, Aharon, "Manna." Pages 104-105 in Exodus (Olam Ha-Tanach). edited by Shemaryahu Talmon and Yitzhak Avishur, Tel-Aviv: Dodzon-iti, 1993 (in Hebrew). 
Sivan, Daniel. "The Internal Passive of G-Stems in Northwest Semitic Languages." Pages 47-56 in Mas'at Aharon: Linguistic Studies Presented to Aaron Dotan. Edited by Moshe Bar-Asher and Chaim E. Cohen. Jerusalem: The Bialik Institute, 2009 (in Hebrew).

. A Grammar of the Ugaritic Language. Leiden: Brill, 2001.

Sokoloff, Michael. A Dictionary of Jewish Palestinian Aramaic of the Byzantine Period. Ramat-Gan: Bar-Ilan University Press, 1990.

. A Dictionary of Jewish Babylonian Aramaic of the Talmudic and Geonic Periods. Ramat-Gan: Bar-Ilan University Press, 2002.

. Syriac Lexicon, A Translation from Latin, Correction, Expansion, and Update of C. Brockelmann's Lexicon Syriacum. Indiana: Eisenbrauns 2009.

Tal, Abraham. "Lexicographic Studies." Pages 319-329 in Hebrew and Arabic Studies, in Honour of J. Blau, Presented by Friends and Students on the occasion of his Seventieth Birthday. Edited by Haggai Ben-Shammai, Tel Aviv/Jerusalem: Graphit (Graph Chen), 1993 (in Hebrew).

. A Dictionary of Samaritan Aramaic, 2 vols. Leiden: Brill, 2000.

Téné, David. Sefer Ha-Hassaga, which is Kitāb Al-Mastalhaq of Rabbi Jonah Ibn Janāḥ in the Hebrew Translation of Obadiah Ha-Sefaradi. Jerusalem: The Academy of the Hebrew Language \& The Bialik Institute, 1996 (in Hebrew).

The Editors of Encyclopaedia Britannica. "Manna," No Pages. Cited 13 April 2020. Online: https://www.britannica.com/topic/manna-plant-product\#ref275090.

Wilensky, Michael. Sefer Ha-Riqma, which is Kitāb Al--Luma of Rabbi Jonah Ibn Janāh, 2 vols. Jerusalem: The Academy of the Hebrew Language, 1964 (in Hebrew).

Dr. Haim Dihi, Researcher and Lecturer, Hebrew Language Department, BenGurion University of the Negev, Beer-Sheva, Israel, Email: deihi@bgu.ac.il, ORCID: https://orcid.org/0000-0001-8458-0302. 